\title{
А. А. Хўжаев
}

Тошкент давлат педагогика университети доценти, педагогика фанлари фалсафа доктори (PhD).

\section{Г. А. Хўжаева}

Тошкент давлат педагогика университети ўқитувчиси

Аннотация. Ушбу мақ̧олада олий таълим муассасаларида ўқ̧итиш самарадорлиги ва таълим сифатини очириш, масофавий таълим шароитида талабаларни бахуолаш хусусида фикр юритилади.

Калит сўзлар: олий таълим тизими, таълим сифати, давлат таълим стандартлари, уукув дастурлари, талабалар билимини бахуолаш, тест тизими.

\section{МЕХАНИЗМЫ ОЦЕНКИ УСПЕВАЕМОСТИ СТУДЕНТОВ В ВЫСШЕМ ОБРАЗОВАНИИ}

\section{А. А. Ходжаев}

Доцент Ташкентского государственного педагогического университета, доктор философии педагогических наук (PhD).

\section{Г. А. Ходжаева}

Преподаватель Ташкентского государственного педагогического университета

Аннотация. $B$ статье рассматриваются эффективность преподавания и качество образования в высшейшколе, оченка студентов в контексте дистанционного обучения.

Ключевые слова: система высшего образования, качество образования, государственные образовательные стандарты, учебные планы, оценка знаний студентов, система тестирования. 
MECHANISMS FOR ASSESSING STUDENT PERFORMANCE IN HIGHER EDUCATION

A. A. Khodjaev
$\begin{gathered}\text { Associate Professor of Tashkent State Pedagogical University, Docto } \\ \text { Philosophy of Pedagogical Sciences }(\mathrm{PhD}) .\end{gathered}$
G. A. Khodjaeva
Lecturer at Tashkent State Pedagogical University

Abstract. The article examines the effectiveness of teaching and the quality of education in higher education, the assessment of students in the context of distance learning.

Key words: higher education system, quality of education, state educational standards, curricula, assessment of students' knowledge, testing system.

Ўқитиш ва тарбиялаш жараёни турли тарихий даврларда вақт хамда ижтимоий муносабатлар даражасига мос тарзда турли шакл ўзгаришларига учраган, бироқ таълимни такомиллаштириш йўллари хақидаги масала хамма вақт долзарб бўлиб қолаверган.

Бугунги кунда кадрлар тайёрлаш масаласига давлат сиёсати даражасида алохида эътибор берилаётгани олий таълим сохасидаги ислохотларнинг янги сифат босқичига кўтарилишидан далолат бермоқда.

Шу билан бирга хозирги замон олий таълим тизими олдида турган долзарб масалалардан бири ўқув жараёнини бошқариш, масофавий таълим шароитида талабаларнинг ўқув ютуқларини шаффоф ва холисона бахолаш орқали таълим сифатини ошириш эканлиги эътироф этилди. Таълим сифати илмий тадқиқот объекти сифатида дунёнинг ривожланган давлатларида кенг ўрганилган ва жорий этилган. Таълим муассасаларида ўқув жараёнида таълим сифатига эътибор сусаймаган бўлсада, эдукологик тизим сифатида энди шаклланмокда.

Юксак замонавий ривожланиш йўлига ўтиш миқёсида мухим ахамиятга эга энг мухим омил фақат техник ғояларни ишлаб чиқариш эмас, балки ички ва ташқи бозорларга харидоргир махсулотлар ишлаб чиқариш, шунингдек, уни амалга ошириш учун илмий - техник соха ва юксак технологияларни ишлаб чиқарувчи малакали мутахассисларини илғор таълим муассасаларида ўқитиш, ўқитишнинг замонавий технологияларини жорий этиш, халқаролашув даражасини ошириш, талабаларнинг академик мобиллигини таъминлашга қаратилиши 


\section{EIP}

лозимлигидир.

Бугунги кун ўқитувчилари таълим жараёнида кўллашлари мумкин бўлган замонавий инновацион услублар, ахборотлар базасига етарли даражада эгадирлар. Бунинг учун замонавий компьютер ва бошқа ахборот коммуникацион технологияларини, электрон дарсликлар, видеоматериаллар, фотоматериалларни, интернетдан етарлича фойдалана олишга ўзини ўргатиши орқали масофавий таълим шаротида самарали ва сифатли таълим олиб бориш компетенцияларини шакллантиришлари зарурятдир. Буларнинг хаммаси педагогик изланувчилик фаолиятини таъминлайди.

Профессор-ўқитувчилар турли хил замонавий педагогик технологияларни қўллаши мумкин. Масалан, фаол ўқитишнинг имитацион усуллари, лойихалар усули, ўқитишда хамкорлик, креатив ўқитиш, маъруза-пресс-конференция, муаммоли ва ўйинли технология, жамоавий ва гурухли фаолият технологияси, турли холатларни тахлил қилиш усули, маъруза-сухбат, визуал маъруза ва бошқалар шулар жумласидандир.

Ў қув-услубий жараёнда замонавий фаолият-педагогнинг ўз касбини такомиллаштиришдаги мавжуд шакл ва воситаларни эгаллашга ижодий ёндашувини назарда тутади. Таълим менежментидаги инновациялар ва замонавий педагогик фаолият хақида барқарор хамда хаммага маъқул бўлган илмий тасаввурлар ва таснифларни янада такомиллаштириш зарурлигини эътироф этиш лозим. Бундай холатнинг асосий сабабларидан бири таълимга йўналтирилган илмий билимлар тизимлари ўртасидаги қийинчилик билан енгиб ўтиладиган узилишлардир. Ўқитувчи замонавий фаолиятнинг субъекти ва ташкилотчиси сифатида янгиликни яратиш, қўллаш хамда оммалаштиришда иштирок этади. У фандаги билим, анъаналардаги ўзгаришлар мазмунини ва мохиятини тахлил эта билиши керак.

Таълим жараёнининг «замонавий» технологиялари талабани нафақат ижтимоий, касбий билимлар билан таъминлайди, балки унда касбига хос сифатлар шаклланишига хам ёрдам беради. Таълим жараёнининг технологияси қуйидаги асосий мақсадларга эришишга хизмат қилади:

- давлат манфаатларига мос холда, талабани бўлажак мутахассис сифатида тайёрлайди;

- талабани жамият аъзоси сифатида шакллантириб, ижтимоий тажриба, қадриятларни, меъёрларни англаган жамият манфаатлари билан хамоханг фаолият кўрсатувчи кадрни тайёрлайди;

- талабани фаол, ташаббускор, креатив фикрлашга қодир шахс сифатида ривожлантиради.

Шуни таъкидлаб ўтиш лозимки, профессор-ўқитувчиларнинг 
замонавий фаолиятга тайёрлигининг мухим ижтимоий ва касбий сифатлари, нафақат таълим муассасасидаги иқтисодий ва молиявий вазиятга, балки бевосита бу сифатларнинг талаб этилганлиги билан хам боғлиқдир. Замонавий олий таълимнинг асосий реал талабларидан бири ўқитувчиларнинг касбий сифатлари ва етарлича малакага эга бўлишидир. Шу жихатдан кадрлар масаласи хозирги куннинг долзарб масалаларидан бири бўлиб қолмоқда. Чунки «Кадрлар масаласини хал этмас эканмиз, саъй-харакатларимиз кутилган натижаларни бермайди, хаётимиз, маънавиятимиз эса ўзгариши қийин бўлади».

Олий таълим муассасалари факультетларида профессорўқитувчилар ёш ўқитувчиларга таълим бериш сирларини ўргатиши, ўқитиш услубларини қўллаш бўйича маслахатлар бериши, интерактив ўқитиш усулларини намоён қилиши зарур.

Натижада ўқитувчилар қуйидагиларга эришадилар:

- ўз фаолиятларини бахолашнинг янги усулларини топиш, касбга бўлган қарашни ўзгартириш;

- педагогик ва ижодий қобилиятларини намоён этиш;

- ўқитувчиларда касбий масъулият ва фидойиликни равожлантиради.

Ўқув жараёни самарадорлигини мониторинг килиш ва доимий назорат қилиш вазифалари нафақат талабаларнинг ўқув фаолияти муваффақиятларини текшириш, балки ўқитиш методларини бахолаш, шунингдек ўқитувчининг ўз -ўзига берган бахосини хам ўз ичига олиши керак. Назорат топшириқлари орасида талабаларнинг ўзи томонидан тузилган вазифаларни хам ажратиб кўрсатиш мумкин. Талабалар учун мухими ўқув жараёнига масъулият билан ёндашиш ва креатив қобилиятларини намоён қила олиш имкониятлари кенгайганини назорат қилиш орқали ишонч хосил қилишдир.

Психологик -методологик адабиётларда билим ва кўникмаларни назорат қилиш масалалари кенг ёритилган. Назоратнинг энг мухим функциялари орасида таълимий, диагностик, прогностик, ривожлантирувчи, йўналтирувчи ва тарбиявий турлари мавжуд $[1,2,3,4]$.

Назорат шакли бўйича индивидуал, гурухли ва фронталга бўлинди. Индивидуал назоратда хар бир талабага алохида топшириқ берилди, уни ташқи ёрдамсиз бажариши керак бўлди Ушбу назорат тури, агар талабаларнинг индивидуал билимлари ва кўникмаларини ўрганиш учун, гурухли назоратда кичик талабалар гурухига (бир неча кишидан иборат) вазифа берилди. Назорат мақсадига қараб гурухларга бир хил ёки дифференциал вазифалар берилиши мумкин. Назоратни ташкил этишнинг гурухли шакли ўқув материалини умумлаштириш ва тизимлаштириш мақсадида такрорлаш учун ишлатилади. Фронтал назоратда, ўқув гурухига умумий вазифалар таклиф этилди. 
Назорат тури бўйича ташқи (ўқитувчи томонидан бошқариладиган), талабаларнинг ўзаро назорати ва ўзи-ўзини назоратга бўлинди. Талабаларнинг ўзаро назорати ва ўзини ўзи назорат қилишни ташкил этиш бир қатор мухим, хам инсонпарвар, хам проффесионал равишдаги (бўлажак ўқитувчилар каби) фазилатларни, масалан, масьулиятни хис қилиш, қабул қилинган қарорларга танқидийлик, уларнинг хатоларини тахлил қилиш каби фазилатларни ривожлантиришга ёрдам беради. Ўзўзини назорат қилиш кўп холларда турли хил бахолаш тизимларининг таркибий қисми хисобланади. Масалан, ўқитишнинг кредит-модуль тизимида талабаларнинг ўкув ютуқларини бахолаш, кредитларни кўчириб ўтказиш имконияти мавжуд деса булади [5]. Яъни, талабалар ўзларининг хар бир модул (фан)ни ўзлаштириш кўрсаткичлари, жумладан ўкув ютуқлари учун ажаритлагн кредитларни тўплаш орқали касбий фаолиятидага мажбурий ва танлов фанларни ўзлаштириш натижасидаги шаклланган компетенцияларини бахолаш учта таркибий қисмдан иборат: бахолаш $=$ (ўқитувчининг бахоси + ўз-ўзини бахолаш + ўртача гурух, гурух томонидан намойиш етилган).

Талабалар билими назорат қилишнинг хозирги кунда рейтинг тизимлари турлича бўлиб, назоратнинг куйидаги турлари мавжуд: дастлабки, жорий, оралиқ ва якуний. Шунингдек, коррекция(тузатиш) назорати хам ажралиб туради. Ушбу назорат турларини аниқлаш учун ўқитишнинг турли босқичларидаги дидактик вазифаларнинг ўзига хослиги асос бўлди. Жорий назорат янги ўкув материалини ўзлаштириш жараёнида амалга оширилади, оралиқ назорат ўрганилган материал (мавзу, бўлим)нинг мухим даражасини ўзлаштиришни текшириш учун ишлатилади; якуний назорат ёрдамида бутун ўкув курси давомидаги мавзуларни ўзлаштириш даражаси аниқлашни тақазо қилади. Коррекция(тузатиш) назоратида талабалар томонидан жорий назорат топшириқларини такроран ўтиши дейилади. Шу орқали, назоратнинг барча турлари ўкув жараёни мантиғини такрорлади. Дастлабки назорат - бу ўкув жараёнини муваффақиятли режалаштириш ва бошқариш учун зарур шарт бўлиб, талабаларнинг дастлабки билим ва кўникмаларини аниқлашга имкон берди.

Ўқитувчи ва талабалар фаолиятининг усуллари, ўкув материалини ўзлаштириш давомида талабалар томонидан қабул қилинадиган билим, кўникма ва малакаларни ўзлаштиришини аниқлаш, назорат қилиш усуллари дейилади.

Назорат усуллари оғзаки сўров, ёзма назорат, стандартлаштирилган назорат ва бошқаларни ўз ичига олади.

Оғзаки сўров фронтал ва индивидуал текширув шаклида амалга оширилди. Фронтал сўровномада қисқа вақт ичида барча талабаларнинг билим даражаси маълум бир савол ёки саволлар гурухи бўйича 158 Education and innovative research 2021 у. №3 
текширилди.

Индивидуал оғзаки сўров жавобининг мазмуни, кетма-кетлиги, қарорлар ва хулосаларнинг мустақиллиги, мантиқий фикрлаш даражаси, талабаларнинг нутқ маданияти жихатидан тўғрилигини очиб беришга имкон берди. Оғзаки тест синовлари, агар билимларни идрок этишнинг мазмунлилигини ва уларни қўллашнинг онгини очиб берса, шунингдек, бу талабаларнинг мустақиллиги ва ижодий фаоллигини рағбатлантирса, муваффақиятли деб хисобланиши мумкин.

Ёзма текширув қисқа вақт ичида кўплаб талабаларнинг билимларини бир вақтнинг ўзида текширишга имкон берди. Ёзма назорат билимларни ўқув амалиётида қўллаш қобилиятини ташхислаш учун ишлатилади ва ўқув интизомининг ўзига хос хусусиятларига қараб диктант, ёзма иш, мустақил иш, тестлар ва иншолар шаклида амалга оширилади.

Мустақил иш - ижодий характерга эга бўлиб, нафақат маълум билим ва кўникмаларни синаб кўриш, балки талабаларнинг ижодий қобилиятларини ривожлантиришга имкон берди. Мустақил иш муайян мавзуни ўрганишдаги ўқув жараёнининг мухим босқичи бўлиб, назорат ишидан олдин туради.

Мустақил иш талабалар томонидан фан мавзуси ёки бўлимни ўрганишдаги муваффақиятини аниқлаш мақсадида ўтказилади. Назорат ишларининг самарадорлиги турли хил мустақил ишларни бажаришда ошди. Ўқитувчи мавзуни ўргатиш жараёнида талабалар томонидан материалнинг ўзлаштирилишини оралиқ назорат иши ёрдамида текширилди. Якуний назорат ишини ўтказишдан мақсад, талабаларнинг маълум бир мавзу, курс бўйича олган билим ва кўникмаларини синашдир. Уй вазифа билимларни тизимлаштиришга мўлжалланган бўлиб, материални такрорлаш ва мустахкамлашга имкон берди. Уни амалга ошириш жараёнида талабалар вақт билан чекланиб қолмайдилар, улар ўқитувчининг ва бошқа шахсларнинг хар қандай ўқув қўлланмаларидан ва маслахатларидан фойдаланишлари мумкин.

Тест билим ва кўникмаларни текшириш усуллари орасида алохида ўрин тутади [6]. Бундай назорат тури натижаларининг объективлиги билан ажралиб туради. Жавоб стандартларининг мавжудлиги хар қандай текширувчига бир хил натижани кўрсатишга имкон берди. Текширишни автоматлаштириш ва талабаларнинг назорат ишларини бажариш вақтини қисқартириш қобилияти талабалар ва ўқитувчининг назорат фаолияти вақтининг пасайишига олиб келди, бу еса назоратнинг частотаси ва мунтазамлигини оширишга имкон берди. Бу эса хозирги даврда масофавий таълим жараёнини амалга оширишда талабаларнинг ўқув ютуқларини бахолашда асосий услуб сифатида қўлланилмокда.

Педагогик тестларни қўллаш мақсадларига кўра, норматив ва мезоний йўналтирилган тестларга таснифлаш мумкин. 
Нормативйўналтирилгантестларнинг (norm-referencedtest)вазифаси, тест топширувчилар гурухини белгиланган сифатлар даражасига қараб саралашни ўз ичига олади. Бундай тестлар умумий талабалар орасидан энг яхши номзодларни аниқлаш учун фойдаланилди. Айнан бир мавзу бўйича тест ўтказиш ахамиятсиздир. Ахамиятли томони, норматив йўналтирилган тестларда топшириқларни бажариш учун фарқлаш қобилиятига эга бўлиш талаб этилди. Агар тестда барча тест топширувчилар тўғри бажарган ёки хеч ким бажармаган топшириқлар бўлса, унда бундай топшириқлар ўчирилиши керак, чунки улар тест топширувчилар рейтингини аниқлашга йўл кўймайди.

Мезонларга йўналтирилган тест (criterion-referenced test) синов ишлари орқали ўкув материалини ўзлаштириш даражасини аниқлашга қаратилган. Тест топширувчилар томонидан индивидуал топшириқни ёки бутун тестни бажариши ёки бажармаслиги (фақат битта тест топширувчига рухсат берилади) ўкув материалини ўзлаштириш ёки ўзлаштирмаслик даражасини белгилайди. Бундай холда, тест (алохида топшириқ) ўз вазифасини бажаради. Таълим жараёни давомида жорий ва якуний назоратни ўтказиш учун бундай мезонларга йўналтирилган тестлардан фойдаланилди.

Тест сўзининг таърифида В.С. Ким «тест топшириғи» атамасидан фойдаланган [6]. Бир қатор тадқиқотчилар таъкидлашларича, тестга киритилган барча вазифаларни тест деб аташ мумкин эмас. Тест топшириғини яратиш маълум бир асосий вазифани ишлаб чиқишни ва уни кейинчалик тест топшириғига айлантиришни ўз ичига олади.

М.Б. Челишкова «тест олдидан» ва «тест топшириқлари» ни ажратиб ўтади. «Тест олдидан» топшириғи тестистик топшириқ деб номланиб, агар унинг характеристикаларини микдорий бахолашлар белгиласа, тест топшириқларининг мазмуни, шакли сифатини текширишга ва тизимни шакллантириш хусусиятларини аниқлашга қаратилган баъзи мезонларга жавоб беради.

В.С. Аванесов [7] «тест шаклида топшириқ» ва «тест топшириғи» ни ажратиб ўтади.

Тест шаклидаги топшириқ куйидаги талабларга жавоб берадиган педагогик воситадир:

Мақсадга эга бўлиш;

Қисқалик;

технологик қобилиятлилик (яъни тестларни автоматлаштириш ва натижаларни қайта ишлашга яроқлилиги);

баёнотнинг мантиқий шакли;

жавоб берадиган жойнинг аниклиги;

жавобларни бахолашнинг бир хиллиги; 
вазифа қисмларини тўғри жойлашиши;

барча мавзулар бўйича бир хил кўрсатмалар;

кўрсатманинг топшириқ шакли ва мазмунига мувофиқлиги.

Тест топшириғи - тестниг таркибий бирлиги бўлиб, маълумотлар ва статистик талабларга жавоб беради:

маълум бир қийинчилик;

дифференциал қобилияти (тест натижаларининг етарлича ўзгариши);

топшириқ балларининг бутун тест натижалари билан ўзаро боғлиқлиги, шунингдек бошқа математик ва статистик талаблар [6,7].

Стандартлаштирилган назоратда қўлланиладиган турли хил вазифалар турларига қарамай, тузилиши жихатидан уларни иккита асосий турга фарқлаш мумкин: танланган ва конструктив. Танланган тестлар талабанинг таниб олиш ва эслаш каби фаолиятига асосланиб, эслаб қолиш ва қўшиш асосида тузилади. Танлов тестлари талабаларни таниб олиш ва эсга олишни, конструктив тестлар эса эслаб қолиш ва тўлдириш учун асосланган. Танланган тестлар энг кўп ишлатилган. Бу уларни техник татбиқ этиш, текшириш ва компютер технологияларини синашда ишлатиш қулайлиги билан боғлиқ. Бунда топшириқнинг хар бир саволига бир нечта жавоб вариантлари таклиф этилди, талаба уларнинг орасидан тўғрисини топиши керак бўлди. Тест топшириқлари орасида муқобил, кўп мартали ва ўзаро танловни ажратиш мумкин. Муқобил топшириқ талаба таклиф қилинган саволга «ха» ёки «йўқ» деб жавоб бериши керак бўлган холларда кўлланилди. Жавобни тахмин қилиш эхтимоли юқори бўлганлиги сабабли муқобил топшириқлар бошқа тест топшириқларига нисбатан камроқ қўлланилди. Кўп танлов топшириқлари бир нечта жавобларни танлашни ўз ичига олади.

Ўзаро танлов топшириқлари ёки мос келадиган топшириқлар тасодифий тартибда ёзилган бир нечта саволлар ва бир нечта жавоблар ўртасидаги ёзишмаларни ўрнатишдан иборат. Топшириқлар жавоблари кўшимчалар, формулалар, таърифлар ва хк қўшиш билан якунланади. Топшириқлар матнида талабалар жавобларини расмий, рақамли шаклда ёзадиган тегишли бўшлиқлар мавжуд.

Педагогик тест, хар қандай ўлчов воситаси сингари, маълум бир ишончга эга бўлиши ва бир хил шароитларда ўтказилган ўлчов натижаларининг такрорланишини таъминлаши керак. Ўқитувчи олинган маълумотларнинг ишончлилигига алохида эътибор бериши керак бўлди. Тест саволи ва унга жавоблар иложи борича тўғри жавобни танлаш имкониятини истисно қиладиган тарзда тузилиши керак. Савол тўғри ва равшан шакллантирилиши керак. Тестда на унинг тўғри жавоби, на бошқа саволга жавоби хақида хеч қандай маълумот бўлмаслиги керак. Жавоб вариантларининг сўзлари бир хил услубга мос келиши керак. 
Жавоблардан бирини хажми, мазмуни ёки тест топширувчини диққатини жалб қилишга қодир бўлган бошқа параметрлар бўйича ажратиб кўрсатишга йўл қўйилмайди. Тестнинг ишончлилигини бахолашнинг мураккаблиги ва унинг ёрдамида олинган назорат маълумотларининг валидлигини тест усулининг камчиликлари билан боғлаш мумкин.

Тест назоратининг чекловлари борлиги сабабли, талабанингсамарали ижодий фаолиятини, унинг ривожланиш даражасини, касбий фикрлаш тафаккурини тавсифловчи батафсил семантик жавобни текширишга имкон бермайди. Шунинг учун ушбу усулни билим ва кўникмаларни оғзаки, ёзма ва амалий синовдан ўтказиш билан биргаликда қўллаш керак.

Методларни танлаш ўқитувчи томонидан назорат мақсадларининг келиб чиқишига кўра амалга оширилади. Шуни ёдда тутиш керакки, хар бир назорат қилиш усули ўзининг афзалликлари ва камчиликларига, қўлланилиш сохасига эга. Уларнинг хеч бири ўқув жараёнининг барча жихатларини диагностика қилишга қодир ягона деб тан олиниши мумкин эмас. Фақатгина методик жихатдан мақсадга мувофиқ ва барча усулларнинг асосли комбинацияси ўкув жараёни сифатини оширишга ёрдам беради.

Педагогик (методик) тизим самарадорлигини бахолашнинг вазифаси, эришилган натижаларнинг кутилган (прогноз қилинган) мақсадлар билан ўзаро боғлиқлиги, хисобга олиниши керак бўлган омиллар рўйхатини аниқлаш ва шу омиллар таъсирини хисобга олган холда бир қатор қийинчиликлар миқдорини аниқлаш билан белгиланади.

Педагогик (методик) тизим самарадорлигини бахолашда фақат билимларни ўзлаштириш сифатини аниқлаш билан боғлаш мумкин эмас, лекин сўнгги муаммони хал қилиш натижаларида бу энг объектив назорат тури бўлиши мумкин (масалан, тест ёрдамида).

Тестдан фойдаланиш ушбу усулнинг хусусиятларини хисобга олишни талаб қилади. Кўп танловли тестларнинг камчиликларидан бири шундаки, тест топширувчи тўғри жавобни тахмин қилиши мумкин. Тестдан ўтган тўғри жавоб бошланғич билимларнинг мавжудлиги (ўқув жараёни бошланишидан олдин олинган) ёки жавоб вариантларининг нотўғри тузилганлиги туфайли танланиши мумкин. Демак, тест натижалари учун нолга тенг бўлмаган чегара қиймати мавжуд бўлиб, унга хар қандай ўқимаган тест топширувчиси эришиши мумкин (лекин ошиб кетмайди).

Талабаларнинг тушуниш даражаси «қадриятлар тизими», «харакат қилишга тайёрлиги» ва бошқа бир қатор омиллар билан бирга талабалар билан мулоқот, уларнинг ўқув фаолиятини кузатиш, сухбатлар, сўровлар натижасида аниқланиши мумкин. Бундай шароитда мураккаб билим 
вазифалари ва машқлар тизимларининг диагностик роли нафақат билимларни ўзлаштириш сифатини, балки талабаларнинг маълум машғулотларга тайёргарлигининг бошқа жихатларини бахолашга имкон берадиган усуллар сифатида ортади.

Хулоса қилиб шуни айтишимиз мумкинки методик тизимни шакллантиришнинг мақсади «компитенцияни шакллантириш» сифатида тизимнинг самарадорлигини аниқлаш компитенциясини шакллантириш кўрсаткичлари асосида амалга оширилиши керак. Компитенцияни шакллантириш даражаларини тақсимлаш (масалан, «юқори», «ўрта» ва «паст») методик тизим самарадорлигига эришилган натижаларнинг ўртача қийматлари асосида ва фақат маълум даражалар билан боғлиқ натижаларни хисобга олган холда аниқлаш имкониятини яратди.

Фойдаланилган адабиётлар:

Бабанский, Ю.К. Педагогика : учебное пособие для студентов пед. институтов /Ю.К. Бабанский. - М. : Просвещение, 1988.

Загвязинский,В.И.Теория обучения:Современная интерпретация: учеб. посо-бие для студ. высш. пед. учеб. Заведений / В.И. Загвязинский - М. : Издатель-ский центр «Академия», 2001.

Ким, В.С. Тестирование учебных достижений: монография / В.С. Ким. - Уссу-рийск : Издательство УГПИ, 2007. - 214 с. : ил.

Пидкасистый, П.И. Педагогика : учебное пособие для студентов педагогиче-ских вузов и педагогических колледжей / П.И. Пидкасистый. - М: Педагоги-ческое общество России. - 1998. - 640 с.

Б.Ходжаев, А.Хўжаев. Кредит-модул тизими: имкониятлари ва афзалликлари // НамДУ илмий ахборотномаси, 2020 йил, 5-сон, 511-521 бетлар.

Ким, В.С. Тестирование учебных достижений: монография / В.С. Ким. - Уссу-рийск : Издательство УГПИ, 2007. - 214 с. : ил.

Аванесов, В.С. Форма тестовых заданий / В.С. Аванесов. - М.: Центр тестирования, 2005 - 156 с. 